\title{
Osteogenic Neoplasm
}

National Cancer Institute

\section{Source}

National Cancer Institute. Osteogenic Neoplasm. NCI Thesaurus. Code C6603.

A benign, intermediate, or malignant bone-forming neoplasm. Representative examples

include osteoma, osteoblastoma, and osteosarcoma. 